\section{Susceptibility of Blueberry to Infection by Agrobacterium tumefaciens}

\author{
Lisa J. Rowland ${ }^{1}$ \\ U. S. Department of Agriculture, Agricultural Research Service, Fruit \\ Laboratory, BARC-W, Beltsville, MD 20705
}

Additional index words. Vaccinium corymbosum, transformation

The ability to regenerate various plant species from leaf disks has provided opportunities for their genetic transformation by Agrobactetium tumefaciens (Horsch et al., 1985; Klee et al., 1987; McCormick et al., 1986). The regeneration of cultivated highbush blueberry plants (Vaccinium corymbosum L.) from leaf segments has been accomplished recently at several laboratories (Billings et al., 1988; Callow et al., 1989; Dweikat and Lyrene, 1988). Natural infection of blueberry by Agrobacterium is uncommon. Galls have been rarely observed on field- and nursery-grown blueberry plants and rarely attributed to infection by $A$. $t u$ mefaciens (Demaree and Smith, 1952). The possible resistance of blueberry to infection by Agrobacterium may limit its usefulness for the transformation of blueberry leaf segments. In addition, the susceptibility of blueberry to infection by specific Agrobacterium strains commonly used in transformation experiments has not been previously determined. Therefore, the susceptibility of blueberry to infection by five Agrobactetium strains was investigated.

Groups of six to eight seedlings ( $\approx 6$ months old) were each inoculated with Agrobacterium strains T37, C58, A281, A518, or B6. Seedlings were from a cross between a $V$. corymbosum parent and a $V$. colymbosum $\mathrm{x}$ $V$. elliottii parent. Seedlings to be inoculated were brought into the laboratory and wounded once toward the base of the stem with a sterile scalpel. Ten microliters of 36-hr-old bacterial culture grown in YEP media (1\% yeast extract, $1 \%$ peptone, $0.5 \% \mathrm{NaCl}$ ) was placed on each of the wounded sites. Plants were left in the laboratory $3 \mathrm{hr}$ before being moved to the greenhouse. After $\approx 4$ weeks, no gall

Received for publication 4 Apr. 1990. I acknowledge Paul Lyrene and Gloria Moore, both of the Univ. of Florida, Gainesville, for kindly providing the blueberry seedlings and the Agrobacterium strains, respectively. The cost of publishing this paper was defrayed in part by the payment of page charges. Under postal regulations, this paper therefore must be hereby marked advertisement solely to indicate this fact.

${ }^{1}$ Research Geneticist. formation was apparent. Therefore, the same set of seedlings was returned to the laboratory and inoculated again with the same Agrobacterium strain. Seedlings were wounded a second time with a sterile needle by puncturing young succulent stem tissue several times. Ten microliters of culture was placed on each of the wounded sites. The sites were wrapped with cotton balls moistened with distilled water and then covered with parafilm. Plants were placed in a tray, covered with a plastic sheet to ensure high humidity and to prevent bacteria from drying, and returned to the greenhouse. The cotton and parafilm were removed after $\approx 3$ to 5 days. Plants remained covered with the plastic sheet for $\approx 4$ weeks.

Two of the plants from the first inoculation with A281 had produced galls (Table 1) 5 to 6 weeks after the second inoculations. From the second set of inoculations, one of six seedlings inoculated with T37 and C58 produced galls (Fig. 1). However, no more seedlings inoculated with A281 produced galls. Because of the small number of seedlings, it is not clear whether this variation is significant, i.e., this particular strain favored the first method of inoculation. No plants inoculated with A518 or B6 produced galls even 10 weeks after the second set of inoculations.

Because the number of seedlings inoculated with each Agrobacterium strain was small, resistance of highbush blueberry seedlings to infection by strains A518 and B6 could not be determined. However, high-

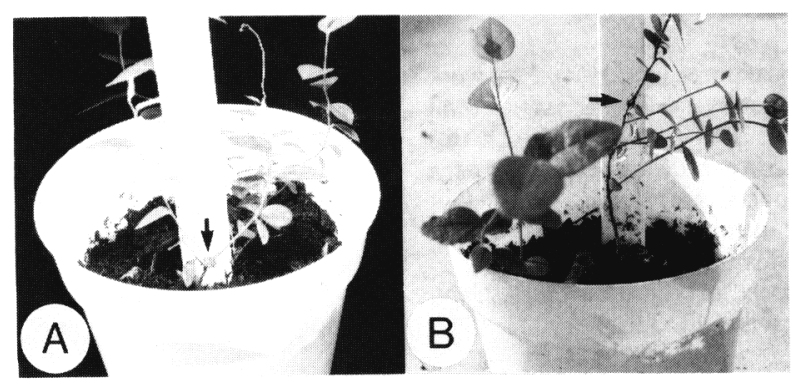

Fig. 1. Gall formation (arrows) on blueberry plants inoculated with Agrobacterium tumefaciens strains T37 (A) and C58 (B).

Callow, P., K. Haghighi, M. Giroux, and J. Hancock. 1989. In vitro shoot regeneration or leaf tissue from micropropagated highbush berry. HortScience 24:373-375.

Demaree, J.B. and N.R. Smith. 1952. Blueberry galls caused by a strain of Agrobacterium tumefaciens. Phytopathology 42:88-90.

Dweikat, I.M. and P.M. Lyrene. 1988. Adventitious shoot production from leaves of blueberry cultured in vitro. HortScience 23:629.

Horsch, R.B., J.E. Fry, N.L. Hoffman, D. Eich holtz, S.G. Rogers, and R.D. Fraley. 1985. A simple and general method for transferring genes into plants. Science 227:1229-1231.

Klee, H., R. Horsch, and S. Rogers. 1987. Agrobacterium-mediated plant transformation a its further applications to plant biology. Annu. Rev. Plant Physiol. 38:467-486.

McCormick, S., J. Niedermeyer, J. Fry, A. Barnason, R. Horsch, and R. Fraley. 1986. Leaf disc transformation of cultivated tomato (L. esculentum) using Agrobacterium tumefaciens. Plant Cell Rpts. 5:81-84.

Table 1. Production of galls on blueberry seedlings after inoculation with various Agrobacterium fumefaciens strains. bush blueberry clearly is susceptible to infection by at least three Agrobacterium strains-A218, T37, and C58. Disarmed (nongall-inducing) derivatives of these strains are available and are routinely used in transformation experiments with other plant species. The use of Agrobacterium tumefaciens to transform blueberry appears promising.

\section{Literature Cited}

Billings, S.G., C.K. Chin, and G. Jelenkovic. 1988. Regeneration of blueberry plantlets from leaf segments. HortScience 23:763-766.

\begin{tabular}{lcc}
\hline \hline & \multicolumn{2}{c}{$\begin{array}{c}\text { Fraction of } \\
\text { seedlings } \\
\text { with galls }\end{array}$} \\
\cline { 2 - 3 } $\begin{array}{c}\text { Agrobacterium } \\
\text { strain }\end{array}$ & $\begin{array}{c}\text { First } \\
\text { inoculation }\end{array}$ & $\begin{array}{c}\text { Second } \\
\text { inoculation }\end{array}$ \\
\hline T37 & $0 / 8$ & $1 / 6$ \\
C58 & $0 / 8$ & $1 / 6$ \\
A281 & $2 / 8$ & $0 / 8$ \\
A518 & $0 / 8$ & $0 / 7$ \\
B6 & $0 / 8$ & $0 / 6$ \\
Control & $0 / 7$ & $0 / 7$ \\
\hline
\end{tabular}

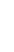

